\title{
EDB fibronectin and angiogenesis - a novel mechanistic pathway
}

\author{
Zia A. Khan ${ }^{1,4}$, Bosco M. Chan ${ }^{2,3}$, Shashi Uniyal ${ }^{2,3}$, Yousef P. Barbin ${ }^{1}$, Hana Farhangkhoee ${ }^{1}$, Shali Chen $^{1} \&$ \\ Subrata Chakrabarti ${ }^{1,2}$ \\ ${ }^{1}$ Department of Pathology, University of Western Ontario, London, Ontario, Canada; ${ }^{2}$ Department of Microbiology and \\ Immunology, University of Western Ontario, London, Ontario, Canada; ${ }^{3}$ Biotherapeutics Research Group, Robarts Re- \\ search Institute, London, Ontario, Canada; ${ }^{4}$ Present address: Vascular Biology Research Program, Department of Surgery, \\ Children's Hospital Boston, Harvard Medical School, Boston, Massachusetts, USA
}

Received 21 January 2005; accepted in revised form 2 May 2005

Key words: angiogenesis, cancer, diabetes, oncofetal fibronectin, tumorigenesis

\begin{abstract}
Extra domain-B containing fibronectin $\left(\mathrm{EDB}^{+} \mathrm{FN}\right)$, a recently proposed marker of angiogenesis, has been shown to be expressed in a number of human cancers and in ocular neovascularization in patients with proliferative diabetic retinopathy. To gain molecular understanding of the functional significance of $\mathrm{EDB}^{+} \mathrm{FN}$, we have investigated possible regulatory mechanisms of induction and its role in endothelial cell proliferation and angiogenesis. Human vascular endothelial cells were cultured in high levels of glucose, and fibrogenic growth factors, transforming growth factor- $\beta 1$ (TGF- $\beta 1$ ) and endothelin-1 (ET-1). Our results show that high glucose levels, TGF- $\beta 1$, and ET-1 upregulated $\mathrm{EDB}^{+} \mathrm{FN}$ expression. Treatment of cells exposed to high glucose with TGF- $\beta 1$ neutralizing antibody and ET receptor antagonist prevented high glucose-induced $\mathrm{EDB}^{+} \mathrm{FN}$ expression. In order to elucidate the functional significance of $\mathrm{EDB}^{+} \mathrm{FN}$ upregulation, cells were subjected to in vitro proliferation and angiogenesis assays following EDB peptide treatment and specific EDB ${ }^{+} \mathrm{FN}$ gene silencing. Our results show that exposure of cells to EDB peptide increased vascular endothelial growth factor (VEGF) expression, endothelial proliferation, and tube formation. Furthermore, specific $\mathrm{EDB}^{+} \mathrm{FN}$ gene silencing prevented both basal and high glucose-induced VEGF expression and reduced the proliferative capacity of endothelial cells. In conclusion, these results indicate that $\mathrm{EDB}^{+} \mathrm{FN}$ is involved in endothelial cell proliferation and vascular morphogenesis, findings which may provide novel avenues for the development of anti-angiogenic therapies.
\end{abstract}

\section{Introduction}

Angiogenesis is an important physiological phenomenon which occurs during development and wound healing. However, unregulated angiogenesis is the key mechanism underlying many pathological conditions including tumorigenesis, chronic inflammation, and non-tumoral neovascularization such as proliferative diabetic retinopathy $[1,2]$. Formation of new vascular network entails interactions between vascular endothelial cells and the extracellular matrix (ECM) [3]. It is increasingly being realized that ECM is more than a mere bystander. The composition of the ECM is important in various physiological and pathological

Correspondence to: Subrata Chakrabarti, Department of Pathology, University of Western Ontario, Dental Sciences Building, Room 4011, London, Ontario, Canada. Tel: + 1-519-685-8500, ext. 36350; Fax: +1-519-661-3370; E-mail: subrata.chakrabarti@fmd.uwo.ca conditions [3]. One of the most predominant and specialized proteins in the ECM, fibronectin $(\mathrm{FN})$, has been shown to undergo alternative splicing exclusively during embryogenesis and tumorigenesis [4-10]. These splice variants called extra domain-B $\left(\mathrm{EDB}^{+}\right) \mathrm{FN}$ species have recently been proposed to be markers of tumoral angiogenesis [4-7, 10]. However, no definitive reports provide evidence of functional significance of these splice variants in the context of either tumoral or non-tumoral angiogenesis.

$\mathrm{EDB}^{+} \mathrm{FN}$ has gained significant interest because of the observation that this isoform is present in neoplastic tissue blood vessels and is virtually absent in mature/adult tissues. However, in the context of non-tumoral angiogenesis, we have shown preferential upregulation of $\mathrm{EDB}^{+} \mathrm{FN}$ in vitreous specimens from patients with proliferative diabetic retinopathy (PDR), a condition which entails proliferation of microvascular endothelial cells and retinal neovascularization [7]. 
In addition, we have shown increased expression of $\mathrm{EDB}^{+} \mathrm{FN}$ in the retinal tissues of diabetic rats [7]. Such aberrant expression of embryonic forms of FN may be mediated, at least in part, through transforming growth factor- $\beta 1$ (TGF- $\beta 1$ ) and endothelin-1 (ET-1) [7]. Concurrent analysis of the other FN isoform, extra domain-A $\left(\mathrm{EDA}^{+}\right) \mathrm{FN}$, revealed no significant alteration in PDR [7]. $\mathrm{EDA}^{+} \mathrm{FN}$ expression has been shown to increase in response to tissue injury while its role in cancer is controversial [11]. These studies suggest that angiogenesis, both tumoral and non-tumoral, is associated specifically with increased levels of $\mathrm{EDB}^{+} \mathrm{FN}$ species prompting investigation of possible functional role.

TGF- $\beta 1$ and ET- 1 are potent fibrogenic molecules that are also implicated in vascular endothelial cell proliferation and migration. Although, TGF- $\beta$ has been reported to exhibit anti-proliferative activity in vitro, it is implicated in a positive regulation of angiogenesis in vivo [12]. Such inconsistency in the role of TGF- $\beta$ in cultured cells may be arbitrated by the culture conditions. TGF- $\beta$ has been shown to increase endothelial cell proliferation in a concentration- and cell density-dependent manner [13, 14]. In further support of a pro-angiogenic role of TGF- $\beta$ are the findings, which demonstrate that TGF- $\beta$ acts as a chemoattractant for various cell types which are capable of producing angiogenic factors such as vascular endothelial growth factor (VEGF) [15]. TGF- $\beta$ has also been shown to upregulate both VEGF and ET-1 expression in endothelial cells $[16,17]$. ET-1 is a potent mitogen for endothelial cells [18]. Several tumor cell lines have been shown to upregulate ET-1 production [19]. It has further been demonstrated that selective $\mathrm{ET}_{\mathrm{B}}$ receptor antagonist prevents endothelial cell proliferation and migration, two fundamental steps in the process of angiogenesis [20].

The response of endothelial cells to TGF- $\beta$ and ET- 1 could be modulated by the ECM proteins. We hypothesize that TGF- $\beta 1$ and ET- 1 confer an angiogenic phenotype on endothelial cells via the regulation of ECM protein composition. In this study, we have investigated the mechanisms inducing $\mathrm{EDB}^{+} \mathrm{FN}$ expression in endothelial cells. To do this, we have generated a polyclonal antibody against the EDB domain which was used to characterize $\mathrm{EDB}^{+} \mathrm{FN}$ protein expression. In addition, we have elucidated a possible functional role of $\mathrm{EDB}^{+} \mathrm{FN}$ which could potentially explain pathogenetic alterations of endothelial cell behavior in both tumoral and non-tumoral angiogenesis.

\section{Materials and methods}

\section{Endothelial cell cultures}

Human umbilical vein endothelial cells (HUVECs; American Type Culture Collection, Rockville, MD) were cultured as previously described [21]. Briefly, HUVECs were plated at approximately $2500 \mathrm{cells} / \mathrm{cm}^{2}$ in endothelial cell growth medium (Clonetics, Walkersville, Maryland). Endothelial cell growth media, modified MCDB 131 formulation, was supplied with $10 \mathrm{mg} / 1$ human recombinant epidermal growth factor, $1.0 \mathrm{mg} / 1$ hydrocortisone, $50 \mathrm{mg} / 1$ Gentamicin, $50 \mathrm{mg} / 1$ Amphotericin B, $12 \mathrm{mg} / \mathrm{l}$ bovine brain extract, and $10 \%$ fetal bovine serum. Sub-confluent cells were cultured in serum-free media for $24 \mathrm{~h}$ before exposure to glucose and other agents. To determine optimal glucose concentration, sub-confluent cells were incubated with $5 \mathrm{mM}$ (control), 15, 25, or $35 \mathrm{mM}$ D-glucose for $24 \mathrm{~h}$. Following incubation, RNA was extracted and subjected to real time RT-PCR with respect to total $\mathrm{FN}$ and $\mathrm{EDB}^{+} \mathrm{FN}$ mRNA expression. Total FN mRNA $\left(\mathrm{EDB}^{+}+\mathrm{EDB}^{-}\right)$was quantified by designing primers to amplify a $\mathrm{FN}$ site which is not subjected to alternative splicing. Following doseresponse experiments, HUVECs were either incubated in $5 \mathrm{mM}$ glucose (control) or empirically determined high glucose (HG) levels which produced maximal $\mathrm{EDB}^{+} \mathrm{FN}$ mRNA upregulation. In order to determine whether endothelial activation, independent of high levels of glucose, can induce total $\mathrm{FN}$ and $\mathrm{EDB}^{+} \mathrm{FN}$ expression, we analyzed mRNA levels of total FN and $\mathrm{EDB}^{+} \mathrm{FN}$ following incubation of the endothelial cells with varying serum concentrations $(0 \%, 5 \%$ and $20 \%$ fetal bovine serum).

The role of fibrogenic proteins in mediating the effects of high glucose was elucidated by treating cells in $5 \mathrm{mM}$ glucose with $1 \mathrm{ng} / \mathrm{ml}$ recombinant human TGF- $\beta 1$ (Sigma-Aldrich, St. Louis, Missouri) or $5 \mathrm{nM}$ ET-1 (Peninsula Laboratories, Belmont, California). In addition, we incubated cells in (HG) with either $10 \mathrm{ng} /$ $\mathrm{ml}$ TGF- $\beta 1$ neutralizing antibody (Sigma-Aldrich) or $10 \mu \mathrm{M}$ dual ET receptor antagonist, bosentan [22] (Courtesy of M. Clozel, Actelion Ltd, Allschwill, Switzerland). In some experiments, TGF- $\beta 1$ neutralizing antibody and bosentan were co-administered. Concentrations of peptides and inhibitors were in accordance with manufacturer's recommendations. Following $24 \mathrm{~h}$ of the treatment period, total RNA and proteins were extracted and subjected to real time RT-PCR for gene expression analyses and western blotting for protein expression analyses.

\section{Real time RT-PCR}

Real time RT-PCR was performed in LightCycler ${ }^{\mathrm{TM}}$ (Roche Diagnostics Canada, Quebec, Canada) as previously described [23]. The reaction mixture $(20 \mu \mathrm{l}$ volume) consisted of $10 \mu \mathrm{l} \mathrm{SYBR}{ }^{\circledR}$ Green Taq ReadyMix (Sigma-Aldrich), $1.6 \mu \mathrm{l}$ of $25 \mathrm{mM} \mathrm{MgCl}, 1 \mu \mathrm{l}$ of each forward and reverse $10 \mu \mathrm{M}$ primers (Table 1), $5.4 \mu \mathrm{l} \mathrm{H}_{2} \mathrm{O}$, and $1 \mu \mathrm{l}$ cDNA template. ET- 1 and TGF$\beta 1$ transcripts were quantified by Taqman $^{\mathrm{TM}}$ probes which were designed using primer express v2.0 (Applied Biosystems, Foster City, California). The 
Table 1. Oligonucleotide sequences for end point and real time RT-PCR.

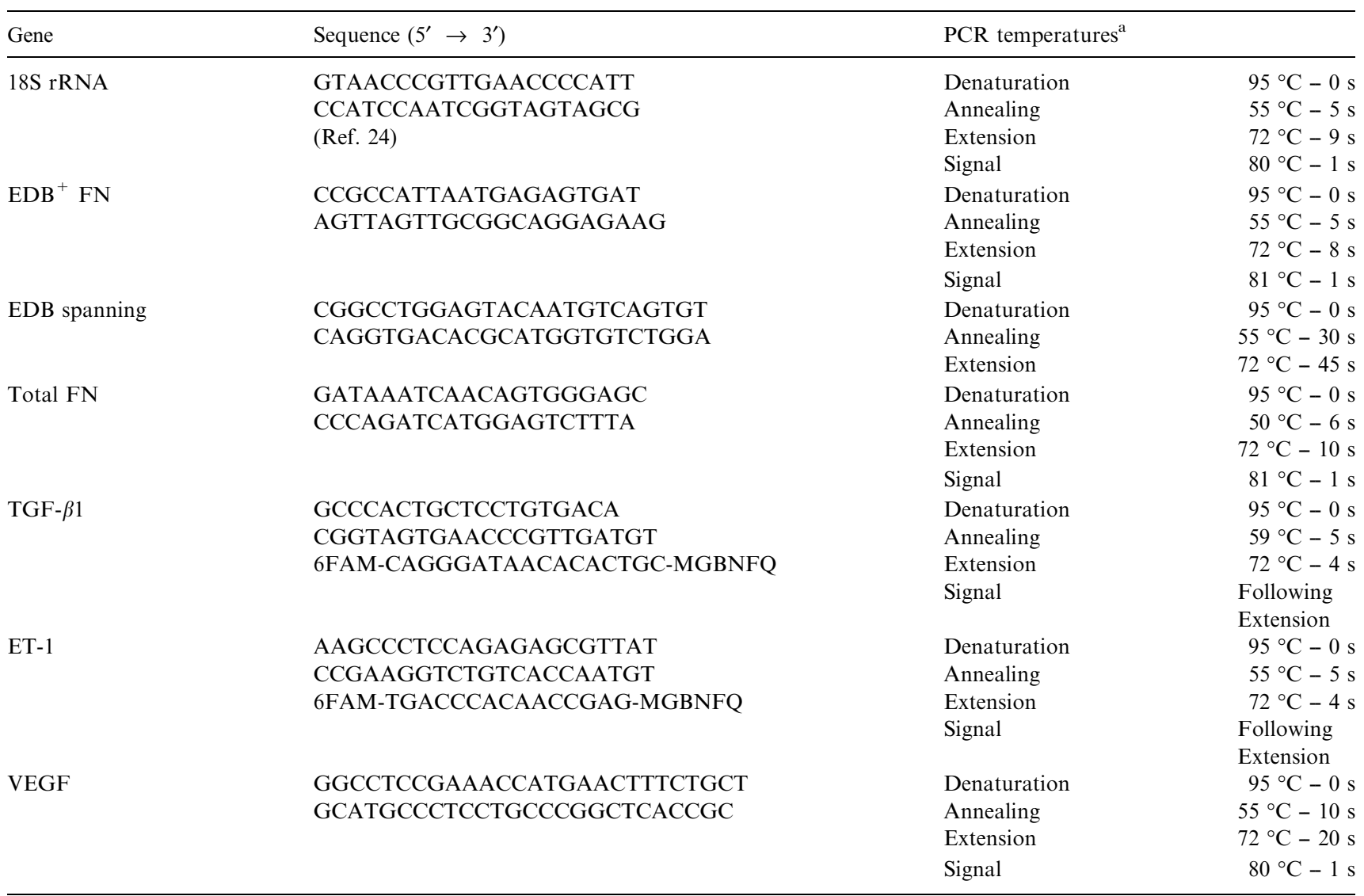

${ }^{\mathrm{a}}$ Initial denaturation was carried out at $95{ }^{\circ} \mathrm{C}-1 \mathrm{~min}$ for real time RT-PCR and 5 min for end point RT-PCR. Ramp rate for real time RT-PCR phases was $20{ }^{\circ} \mathrm{C} / \mathrm{s}$.

PCR reaction mixture for $\mathrm{ET}-1$ and $\mathrm{TGF}-\beta 1$ consisted of $2.5 \mu \mathrm{l} 10 \times$ PCR Buffer (Invitrogen Inc.), $1.25 \mu \mathrm{l}$ of $5 \mathrm{mM}$ dNTP, $1.2 \mu \mathrm{l} 50 \mathrm{mM} \mathrm{MgCl}_{2}, 1 \mu \mathrm{l}$ primers, $10.8 \mu \mathrm{l} \mathrm{H}_{2} \mathrm{O}, 1 \mu \mathrm{l}$ cDNA, and $0.75 \mu \mathrm{l} 15 \mathrm{mM}$ Taqman probes. The data were normalized to housekeeping gene (18S rRNA; ref. 24) to account for differences in reverse transcription efficiencies and amount of template in the reaction mixtures.

Serial dilutions of the standard template (positive control) were used to construct a standard curve and identify cycle numbers in which amplification is exponential vs. $\log$ concentration. In order to accurately compare expression of all genes, we have optimized the reactions such that the average slope of all the standard curves was $-3.29 \pm 0.28$. Such a slope represents a PCR efficiency of 2.013 (doubling of cDNA with each PCR cycle) allowing us to compare the expression level of all genes accurately.

\section{Western blotting}

Total proteins from endothelial cells were isolated and quantified as described previously [23]. Briefly, cells were homogenized in lysis buffer $(0.15 \mathrm{M} \mathrm{NaCl}, 1 \%$ deoxycholate, $50 \mathrm{mM}$ Tris- $\mathrm{HCl}(\mathrm{pH} 7.5), 1 \%$ Triton $\mathrm{X}-100$, and $0.1 \%$ sodium dodecyl sulfate) and protease inhibitor. Total proteins were then quantified by using BCA protein assay kit (Pierce Endogen, Rockford, Illinois, USA). Protein levels were determined by western blotting using polyclonal rabbit anti-human FN (Dako Diagnostics, Canada) (1:1000), EDB immune serum (1:200), rabbit anti-human ET-1 (Peninsula Lab., Belmont, California) (1:1000), and rabbit anti-human TGF- $\beta 1$ (Promega Corp., Madison, Wisconsin) (1:1000) antibody followed by secondary antibody conjugated with horseradish peroxide $(1: 10,000)$. ECL-PLUS Western Blotting Detection kit (Amersham Parmacia Biotech, Piscataway, New Jersey) was used for detection.

\section{Immunofluorescence}

Endothelial cells were cultured in 12 well plates (Fisher Scientific, Canada) with coverslips. Sub-confluent cells were treated with $25 \mathrm{mM}$ glucose for $24 \mathrm{~h}$ as described above. Immunofluorescent microscopy was performed on methanol-fixed permeabilized cells by using $\mathrm{EDB}^{+}$ FN immune serum (1:200) followed by fluorescein anti-mouse secondary antibody (Vector Laboratories, Ontario, Canada) and a confocal microscope equipped with UV and FITC/TRITC filters (Zeiss LSM 410; Carl Zeiss Canada Ltd., Ontario, Canada). To show 
FN fibrils, cells were fixed in $4 \%$ paraformaldehyde and stained with Texas Red anti-mouse secondary antibody (Vector Laboratories, Ontario, Canada).

\section{Production of $E D B^{+} F N$ anti-sera}

Antisera against $\mathrm{EDB}^{+} \mathrm{FN}$ was prepared by immunization of BALB/c mice (The Jackson Laboratory, Bar Harbor, Maine) with the synthetic EDB peptide (ITDSSIGLRWTPLNSSTIIGY; ref. 25) conjugated to keyhole limpet hemocyanin (KLH) (Multiple Peptide Systems, San Diego, California). Mice were injected intradermally with an emulsion of the peptide-KLH conjugate $(100 \mu \mathrm{g}$ per mouse) in complete Freund's adjuvant (Difco Laboratories, Detroit, Michigan). Three weeks later, the mice were boosted twice at two weeks interval with $50 \mu \mathrm{g}$ peptide-KLH conjugate emulsified in incomplete Freund's adjuvant (Difco Laboratories, Detroit, Michigan). Immune sera were obtained 10 days after the second boost and characterized by enzyme linked immunosorbent assay (ELISA) using the pre-immune sera as control. Thus, 96-well MaxiSorp plates (Nalge Nunc International, Naperville, Illinois) were coated with $15 \mu \mathrm{g} / \mathrm{ml}$ streptavidin, washed and then blocked with 2\% BSA in PBS. Biotin conjugated peptides were captured at $5 \mu \mathrm{g} / \mathrm{ml}$ concentration. Immune or pre-immune sera at varying dilutions were added and incubated for $3 \mathrm{~h}$. Alkaline phosphatase conjugated goat anti-mouse IgG (Cedarlane Laboratories, Hornby, Canada) was added, incubated for $1 \mathrm{~h}$, and washed. The substrate, $p$-nitrophenyl phosphate, was then added at $1 \mathrm{mg} / \mathrm{ml}$ according to manufacturer's instructions. Antibody binding was detected by reading the absorbance at $405 \mathrm{~nm}$. At $1000 \times$ dilution, the pre-immune serum absorbance was $<0.1$ while the immune serum absorbance was 0.4 . Immune sera from mice with antibody titres at $>1000 \times$ were used in the study.

\section{$E D B^{+} F N$ gene silencing}

We used a siRNA-based technique to specifically silence $\mathrm{EDB}^{+} \mathrm{FN}$ expression in endothelial cells [26]. siRNAs were constructed to target EDB domain of FN using Silencer ${ }^{\mathrm{TM}}$ siRNA construction kit (Ambion Inc., Austin, Texas, USA). Four potential sites in the
EDB domain of human FN mRNA were identified (Table 2). Target sequences were identified by scanning the EDB domain for AA dinucleotide sequences. Oligonucleotides for siRNA generation were synthesized by addition of dinucleotide AA sequence at the $5^{\prime}$ end of target sequence and 8 nucleotide $5^{\prime}$-CCTGTCTC- $3^{\prime}$ leader sequence at the $3^{\prime}$ end. Endothelial cells were transfected with all four EDB siRNAs (100 nM final concentration) in a single reaction using siPORT Lipid siRNA transfection reagent $(1 \mu \mathrm{l}$ reagent per $500 \mu \mathrm{l}$ transfection volume; Ambion Inc.). Seventy-two hours following transfection, gene expression analyses and XTT assays were performed. All siRNA experiments included transfection of endothelial cells with siRNAs which have no sequence homology (negative transfection; mismatched siRNA) with human genome (Ambion Inc.). Real time RT-PCR was used to measure mRNA levels of $\mathrm{EDB}^{+} \mathrm{FN}$ to assess transfection efficiency. Furthermore, we used end point (conventional) RT-PCR with EDB segment spanning primers to determine the degree of gene silencing. End point RT-PCR allows detection of multiple products of one primer set. We have utilized EDB spanning primers which amplify both $\mathrm{EDB}^{+} \mathrm{FN}(416 \mathrm{bp})$ and $\mathrm{EDB}^{-} \mathrm{FN}$ (143 bp).

\section{Endothelial cell proliferation assay}

Endothelial cell proliferative capacity was assessed by 2,3-bis(2-methoxy-4-nitro-5-sulfophenyl)-5-[(phenylamino)carbonyl]-2H-tetrazolium hydroxide (XTT; Sigma--Aldrich). In this assay, viable cells reduce XTT tetrazolium salt into colored formazan compound which is measured using a spectrophotometer providing a reliable means of quantifying cell proliferation [27]. Cells were cultured in 96-well plates to confluence. $\mathrm{EDB}^{+} \mathrm{FN}$ siRNA or negative control siRNA transfections were carried out in serum-free media. In addition, cells (without transfections) were incubated with $50 \mathrm{ng}$ / $\mathrm{ml}, 2 \mu \mathrm{g} / \mathrm{ml}$ EDB peptide, or $2 \mu \mathrm{g} / \mathrm{ml}$ scrambled EDB peptide (ILNISSLYSDTIGTSTIGPRW). Following $72 \mathrm{~h}$ of treatment, $50 \mu \mathrm{l}$ XTT reagent (prepared by adding $25 \mu \mathrm{l}$ of $5 \mathrm{mM}$ phenazine methosulfate to $5 \mathrm{ml}$ of $1 \mathrm{mg} / \mathrm{ml} \mathrm{XTT)} \mathrm{was} \mathrm{added} \mathrm{to} \mathrm{the} \mathrm{wells} \mathrm{and} \mathrm{cells} \mathrm{were}$ incubated for $4 \mathrm{~h}$. Absorbance was measured at $450 \mathrm{~nm}$ to assess cell proliferation.

Table 2. Oligonucleotide sequences for SiRNA synthesis.

\begin{tabular}{llr}
\hline Oligonucleotide sequences $^{\mathrm{a}}\left(5^{\prime} \rightarrow 3^{\prime}\right)$ & & Nucleotide $^{\mathrm{b}}$ \\
\hline EDB1 SiRNA & AAGGTATCCCTATTTTTGAAGCCTGTCTC & \\
& AACTTCAAAAATAGGGATACCCCTGTCTC & $1423-1441$ \\
EDB2 SiRNA & AACTCACTGACCTAAGCTTTGCCTGTCTC \\
& AACAAAGCTTAGGTCAGTGAGCCTGTCTC & $1414-1432$ \\
EDB3 SiRNA & AACCGATTCAAGCATCGGCCTCCTGTCTC \\
& AAAGGCCGATGCTTGAATCGGCCTGTCTC & \\
EDB4 SiRNA & AAGCATCGGCCTGAGGTGGACCCTGTCTC & $1386-1404$ \\
& AAGTCCACCTCAGGCCGATGCCCTGTCTC & $1500-1518$ \\
\hline
\end{tabular}

${ }^{\text {a }}$ Targeted site in EDB region of FN is italicized.

${ }^{b}$ Nucleotide position in reference to Human $\mathrm{EDB}^{+}$FN sequence (Accession number, X07717). 


\section{Tube formation assay}

Tube formation was assessed using a three-dimensional culture method. HUVECs were seeded in 12-well culture plates with growth factor reduced Matrigel $^{\circledR}$ Matrix (BD Biosciences) coated coverslips. Matrigel was allowed to polymerize before seeding cells in complete media. Following cell attachment, the wells were rinsed and collagen gel was added [28]. Treatments were initiated in serum-free media and comprised of media alone, $50 \mathrm{ng} / \mathrm{ml}$ EDB peptide, $2 \mu \mathrm{g} / \mathrm{ml}$ EDB peptide, $20 \mathrm{ng} / \mathrm{ml}$ human plasma $\mathrm{FN}\left(\mathrm{EDB}^{-} \mathrm{FN}\right)$, or $2 \mu \mathrm{g} / \mathrm{ml}$ human plasma FN (Chemicon, Temecula, California). Vascular morphogenesis was evaluated following Mayer's hematoxylin-eosin staining (Sigma Chemical Co.) following $24 \mathrm{~h}$ of treatment. The staining was scored by two investigators unaware of the treatment. The length of capillary like structures was expressed as $\mathrm{mm} / 100 \times$ field.

\section{Statistical analysis}

The data are expressed as mean \pm SEM and were analyzed by ANOVA followed by Student's $t$-test. Differences were considered significant at values of $P<0.05$.

\section{Results}

\section{$E D B^{+} F N$ expression in endothelial cells}

To elucidate the mechanistic basis of $\mathrm{EDB}^{+} \mathrm{FN}$ expression, we studied endothelial cells, one of the major contributors of $\mathrm{FN}$ to the vasculature. Incubation of endothelial cells in high glucose, which has been shown to increase proliferation of endothelial cells [29], increased transcript levels of both total $\mathrm{FN}$ as well as relative $\mathrm{EDB}^{+} \mathrm{FN}\left(\mathrm{EDB}^{+} \mathrm{FN}\right.$ :Total $\left.\mathrm{FN}\right)$ in a dosedependent manner (Figures 1a, b). In order to determine whether upregulation of $\mathrm{EDB}^{+} \mathrm{FN}$ by high levels of glucose is mediated via elaboration of fibrogenic growth factors, we exposed endothelial cells to TGF- $\beta 1$ and ET- 1 peptides. Treatment of cells with TGF- $\beta 1$ and ET-1 upregulated total FN as well as $\mathrm{EDB}^{+} \mathrm{FN}$ expression (Figures 1c, d). Conversely, cells pre-treated with TGF- $\beta 1$ neutralizing antibody or dual ET receptor antagonist, bosentan, prior to high glucose showed normalization of $\mathrm{EDB}^{+}$FN mRNA levels (Figure 1d). Similar to our previous studies in microvascular endothelial cells [7], high glucose-induced total FN and $\mathrm{EDB}^{+} \mathrm{FN}$ expression in macrovascular endothelial cells (HUVECs) was completely inhibited by co-administration of TGF- $\beta 1$ neutralizing antibody and bosentan (data not shown). In parallel to $\mathrm{EDB}^{+} \mathrm{FN}$ expression, both TGF- $\beta 1$ and ET-1 were found to be increased by high glucose concentration, TGF- $\beta 1$ peptide, and ET- 1 peptide treatment (Figures 1e, f). It is interesting to note that both TGF- $\beta 1$ and ET-1 exhibited autoregulation.
Exposure of cells to TGF- $\beta 1$ increased the respective transcript levels and also modulated ET-1 expression. Similar results were obtained with ET-1 peptide exposure. These findings suggest that the high glucose-mediated TGF- $\beta 1$ and ET- 1 upregulation may lead to induction and re-expression of $\mathrm{EDB}^{+} \mathrm{FN}$ by the vascular endothelial cells.

Our next objective was to investigate whether $\mathrm{EDB}^{+} \mathrm{FN}$ induction represents a general property of activated endothelial cells or whether it represents a specific effect of high glucose concentration and exposure to fibrogenic factors. We cultured endothelial cells in varying serum concentrations and assayed for $\mathrm{FN}$ mRNA expression. Our results show that increasing serum levels did not cause a significant change in the transcript levels of either total $\mathrm{FN}$ or relative $\mathrm{EDB}^{+}$ FN (Figures 2a, b). These results suggest that $\mathrm{EDB}^{+}$ FN induction may be an important event in glucosemediated endothelial cell alterations.

\section{$E D B^{+} F N$ antibody characterization}

We have generated EDB FN antibody to study the $\mathrm{EDB}^{+} \mathrm{FN}$ protein expression and localization. We used both ELISA and western blotting to characterize our antibody. Immunoblot analysis of HUVEC protein with either total $\mathrm{FN}$ antibody or $\mathrm{EDB}^{+} \mathrm{FN}$ antibody revealed similar banding pattern, indicating specificity of our $\mathrm{EDB}^{+} \mathrm{FN}$ antibody (Figure 3a). Our ELISA results further show that EDB antibody binds to biotinylated EDB peptide captured on streptavidincoated wells (Figure 3b). Moreover, pre-immune sera failed to produce a detectable absorbance reading. These findings suggest that $\mathrm{EDB}^{+} \mathrm{FN}$ antibody recognizes the EDB segment of FN.

In order to further confirm the specificity, we performed western blot analysis using purified human plasma $\mathrm{FN}\left(\mathrm{EDB}^{-} \mathrm{FN}\right.$; Ref. 30) with either total $\mathrm{FN}$ antibody or EDB antibody (Figures 3c, d). Circulating form of FN is devoid of EDB segment, therefore, no detection of varying concentrations $(5,10$, and $20 \mu \mathrm{g})$ of plasma FN with EDB antibody would indicate that the antibody does not bind to other FN species or FN repeats. Total FN antibody, however, would be expected to accurately detect the different concentrations of plasma FN. Our data show that EDB antibody failed to detect plasma FN which lacks the EDB segment (Figures 3c, d). However, antibody recognizing total FN showed a linear association with increasing plasma FN concentration. We next detected endothelial protein with increasing concentrations of plasma FN with both total and EDB FN antibodies (Figures 3 e, f). Ten microgram of endothelial protein with increasing plasma FN protein levels increased the band intensity only with total FN detection and not with the $\mathrm{EDB}^{+} \mathrm{FN}$ detection (Figures 3e, f). As plasma FN lacks the EDB domain, these results confirm that EDB antibody recognizes the EDB segment of $\mathrm{FN}$ and not other regions of the molecule. 

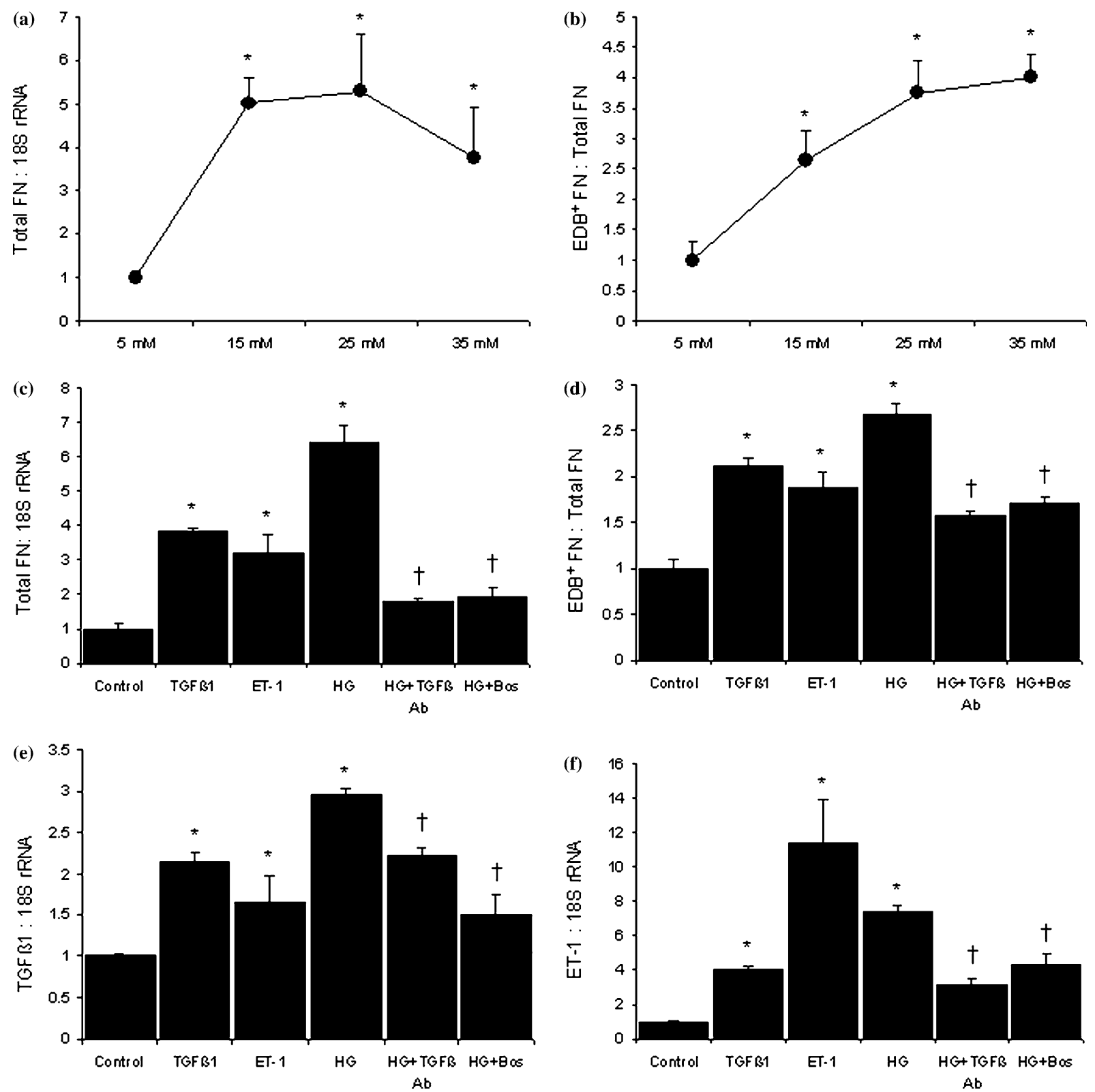

Figure 1. $\mathrm{EDB}^{+} \mathrm{FN}$ expression in endothelial cells. Following $24 \mathrm{~h}$ of incubation with varying glucose concentrations, RNA was extracted and subjected to real time RT-PCR with respect to total FN (a) and relative $\mathrm{EDB}^{+} \mathrm{FN}$ (b) mRNA expression [Total FN is expressed as ratio of target to $18 \mathrm{~S}$ rRNA; $\mathrm{EDB}^{+} \mathrm{FN}$ is expressed as ratio of target to total FN]. (c-f) Real time RT-PCR analysis of total FN, EDB ${ }^{+}$FN, TGF- $\beta 1$, and ET- 1 mRNA levels in endothelial cells following $24 \mathrm{~h}$ of treatment. $(n=5 /$ treatment; $* P<0.05$ as compared to control; $† P<0.05$ as compared to HG).

\section{$E D B^{+} F N$ protein expression in endothelial cells}

In order to determine whether alterations of mRNA expression coincide with alterations of protein levels, we performed western blot analyses (Figure 4a). Our data indicate upregulation of total FN as well as $\mathrm{EDB}^{+} \mathrm{FN}$ protein levels in endothelial cells exposed to high glucose concentration, TGF- $\beta 1$, and ET-1 peptide (Figures $4 \mathrm{a}-\mathrm{c}$ ). The changes in total $\mathrm{FN}$ as well as $\mathrm{EDB}^{+} \mathrm{FN}$ protein levels, although significant, were found to be modest compared to our mRNA data. It is plausible that a modest increase in protein, in comparison to the level of increase in mRNA, is due to the difference in efficiency of the antibodies. In order to assess such a possibility, we performed western blotting with varying concentrations of total endothelial cell protein. Our results suggest that doubling the concentration of endothelial cell protein produces a more pronounced change in densitometric analysis of total $\mathrm{FN}$ as compared to $\mathrm{EDB}^{+} \mathrm{FN}$ (data not shown). However, regression analysis revealed a linear association between densitometric reading and concentration $\left(r^{2}=0.99\right.$; data not shown $)$ indicating inter-assay reliability and accuracy.

In parallel to our mRNA data, western blotting shows that inhibition of TGF- $\beta 1$ and ET- 1 activity by neutralizing antibody and bosentan administration completely prevents high glucose-induced upregulation 

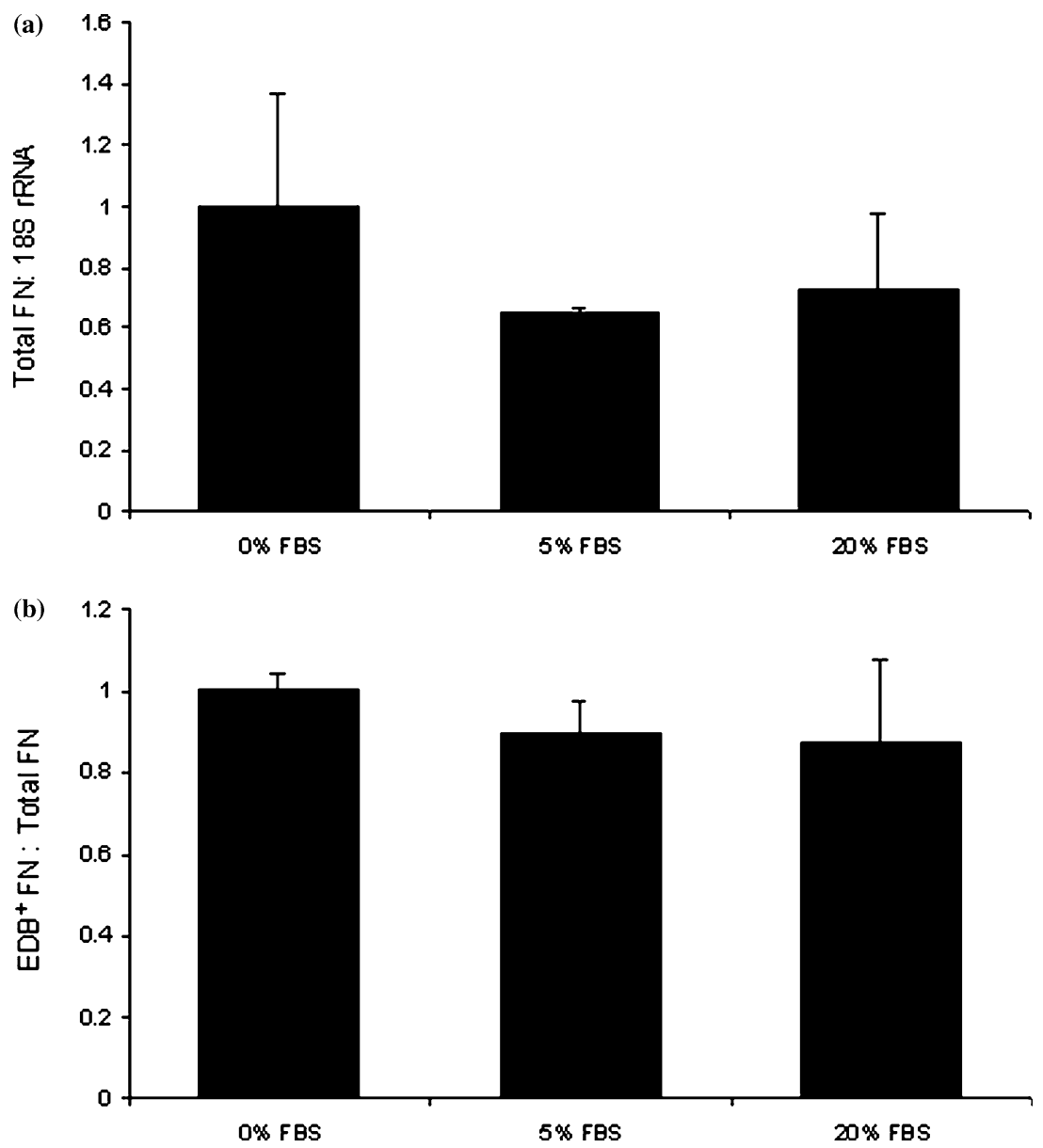

Figure 2. Effect of serum on $\mathrm{EDB}^{+} \mathrm{FN}$ expression in endothelial cells. Following $24 \mathrm{~h}$ of incubation with varying fetal bovine serum concentrations, RNA was extracted and subjected to real time RT-PCR with respect to total FN (a) and relative $\mathrm{EDB}^{+} \mathrm{FN}$ (b) mRNA expression (total FN is expressed as ratio of target to $18 \mathrm{~S}$ rRNA; $\mathrm{EDB}^{+} \mathrm{FN}$ is expressed as ratio of target to total $\mathrm{FN} ; n=5$ /treatment).

of FN species. Furthermore, protein levels of TGF- $\beta 1$ and ET-1 also paralleled our mRNA results (Figures $4 \mathrm{~d}$, e). Immunofluorescent analysis of permeabilized cells also showed that high levels of glucose increase total $\mathrm{FN}$ and $\mathrm{EDB}^{+} \mathrm{FN}$ protein expression (Figures 5a-d). Newly synthesized $\mathrm{EDB}^{+} \mathrm{FN}$ was detected in the cytoplasm of endothelial cells exposed to high levels of glucose. Furthermore, immunofluorescent analyses revealed no morphological changes in endothelial cells due to the upregulation of $\mathrm{EDB}^{+} \mathrm{FN}$. In order to determine whether $\mathrm{EDB}^{+} \mathrm{FN}$ is assembled in fibrils, immunofluorescent analyses were carried out with paraformaldehyde fixation but without permeabilizing the cells. Our results show that $\mathrm{EDB}^{+} \mathrm{FN}$ is assembled in extracellular fibrils (Figures 5e, f).

\section{$E D B^{+} F N$-mediated VEGF}

One of the best characterized angiogenic factors in both physiological as well as pathological blood vessel formation is VEGF [31]. Since EDB ${ }^{+} \mathrm{FN}$ has been shown to be exclusively expressed in neoplastic tissue vessels, we have investigated whether this embryonic FN isoform is involved in regulation of endothelial VEGF expression. To achieve this goal, we transfected endothelial cells with small interfering RNAs (siRNAs) targeted to the EDB domain of FN. This technique is based on introduction of small dsRNA species that act as a guide in the nuclease complex and target cognate mRNA species [26]. Using four constructs in concert, we show a very high transfection and gene knockdown efficiency (Figures $6 a, b)$. As shown by the melting curve analysis and gel electrophoresis of post-PCR products, we are able to completely knockdown $\mathrm{EDB}^{+} \mathrm{FN}$ mRNA. Moreover, using EDB spanning primers, we show that FN mRNA species in siRNA transfected cells are EDB negative (Figure 6c). Such dramatic inhibition of $\mathrm{EDB}^{+} \mathrm{FN}$ mRNA expression resulted in decreased VEGF expression in endothelial cells as compared to non-homologous siRNA transfected cells (negative control) (Figure 6d). Furthermore, inhibition of $\mathrm{EDB}^{+} \mathrm{FN}$ production by siRNA transfection prevented high glucoseinduced VEGF upregulation (Figure 6d). In order to determine whether VEGF reduction was due to toxicity of siRNA transfection, we analyzed other transcripts of interest, such as TGF- $\beta 1$ and ET-1. In contrast to VEGF expression, these transcripts were upregulated in $\mathrm{EDB}^{+} \mathrm{FN}$ siRNA transfected cells possibly indicating a feedback mechanism (Figure 7). These results suggest that $\mathrm{EDB}^{+} \mathrm{FN}$ may be involved in early molecular 

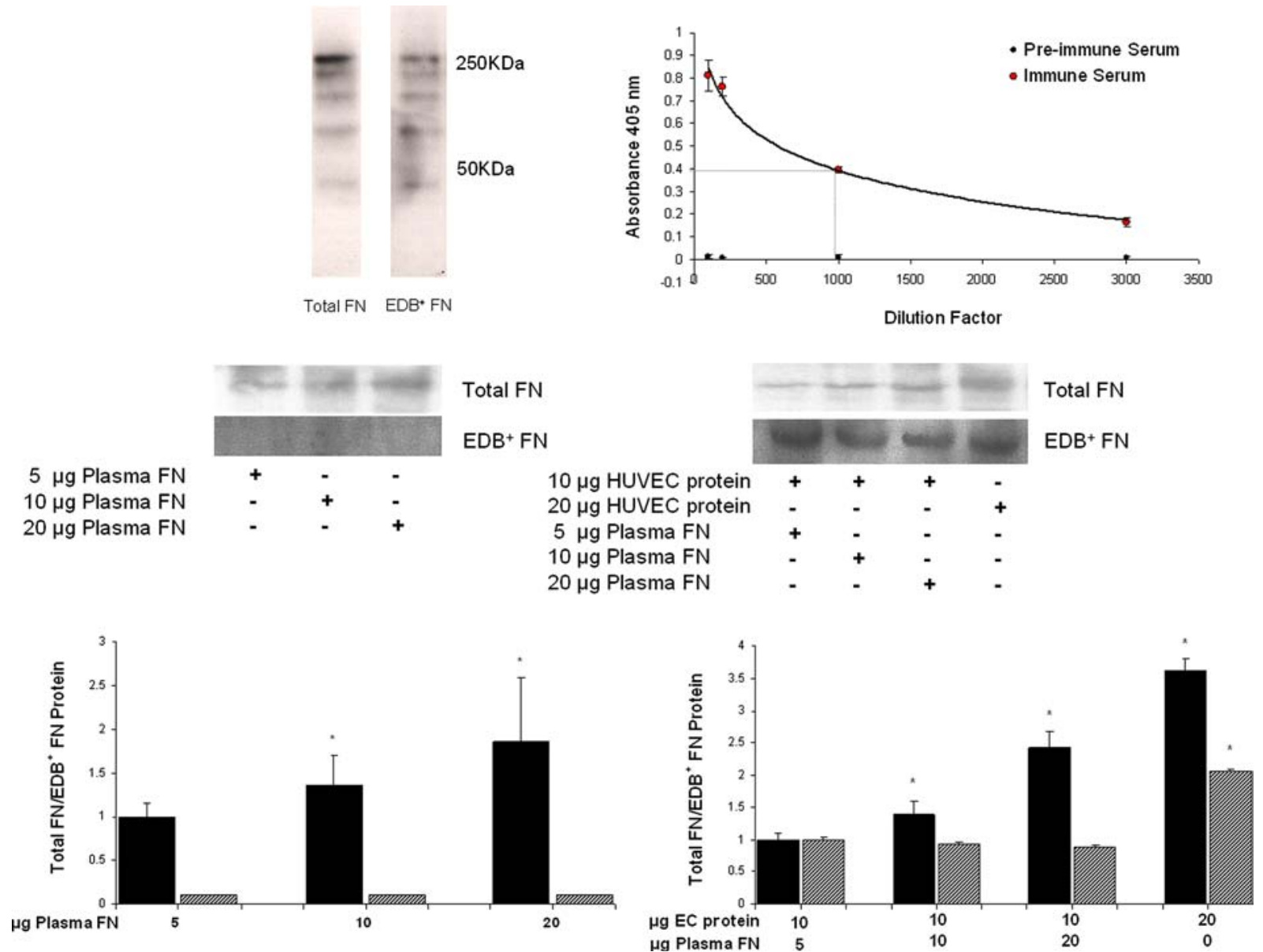

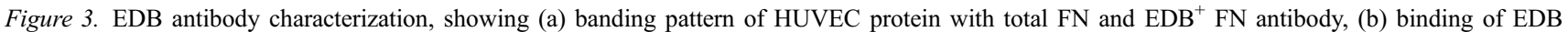
antibody to streptavidin-captured biotinylated EDB peptide (binding was monitored by measuring absorbance at $405 \mathrm{~nm}$; inflection point is shown by dashed line and arrow), (c and d) representative western blot and corresponding densitometric analysis of plasma FN using Total FN (solid bars) and EDB FN (shaded bars) antibodies [EC $=$ HUVEC; ${ }^{*} P<0.05$ as compared to $5 \mu \mathrm{g}$ Plasma FN; $n=3$ ], and (e and f) representative western blot and corresponding densitometric analysis of endothelial protein with or without plasma FN using Total FN (solid bars) and EDB FN (shaded bars) antibodies ( ${ }^{*} P<0.05$ as compared to $10 \mu \mathrm{g}$ endothelial total protein $+5 \mu \mathrm{g}$ Plasma $\mathrm{FN} ; n=3$ ).

alterations which could potentially arbitrate vascular endothelial cell proliferation.

In an attempt to investigate the role of $\mathrm{EDB}^{+} \mathrm{FN}$ in regulation of VEGF expression, we synthesized recombinant human EDB peptide which is recognized by human antibody fragment L19 [25, 32-34]. This antibody fragment has been shown to bind to recombinant EDB FN peptide as well as intact $\mathrm{EDB}^{+} \mathrm{FN}$ with comparable affinity $[4,10,25,30]$. In vivo targeting of newly formed blood vessels with L19 suggests that the segment recognized by the antibody fragment may be accessible in vivo, a region possibly capable of acting as a ligand binding site to transduce extracellular signals. We incubated endothelial cells with the EDB peptide and measured pro-angiogenic VEGF mRNA levels as an early molecular marker of endothelial cell proliferation. In parallel to our siRNA experiments, EDB peptide upregulated the VEGF mRNA expression in a dosedependent manner (Figure 8a). This peptide-mediated VEGF upregulation was completely normalized with anti-sera produced against the EDB peptide (Figure $8 \mathrm{a})$. Treatment of cells with non-immune sera or scrambled peptide, however, failed to alter VEGF expression suggesting a potential role of the EDB segment in regulating the expression of VEGF.

In order to further characterize the involvement of EDB peptide in VEGF expression and to elucidate possible interaction of the peptide with cell surface associated $\mathrm{EDB}^{+} \mathrm{FN}$, we carried out a pre-EDB immune serum treatment before exposing cells to the EDB peptide. Our results indicate that cells pre-treated with EDB immune serum exhibit, although significant, less pronounced neutralization of peptide-mediated effects (Figure 8b). Exogenous EDB peptide could potentially have agonist-like effects or it may behave as a competitive inhibitor of intact $\mathrm{EDB}^{+} \mathrm{FN}$ deposited by the endothelial cells in culture. However, our data show that pre-treatment of cells, which is expected to mask the EDB domain of intact FN, is unable to completely neutralize the EDB peptide-mediated changes. These results suggest that $\mathrm{EDB}^{+} \mathrm{FN}$ may regulate VEGF expression, in part, via interacting with endothelialderived intact $\mathrm{EDB}^{+} \mathrm{FN}$ by the process of fibrillogenesis. However, such notions require further investigation. 

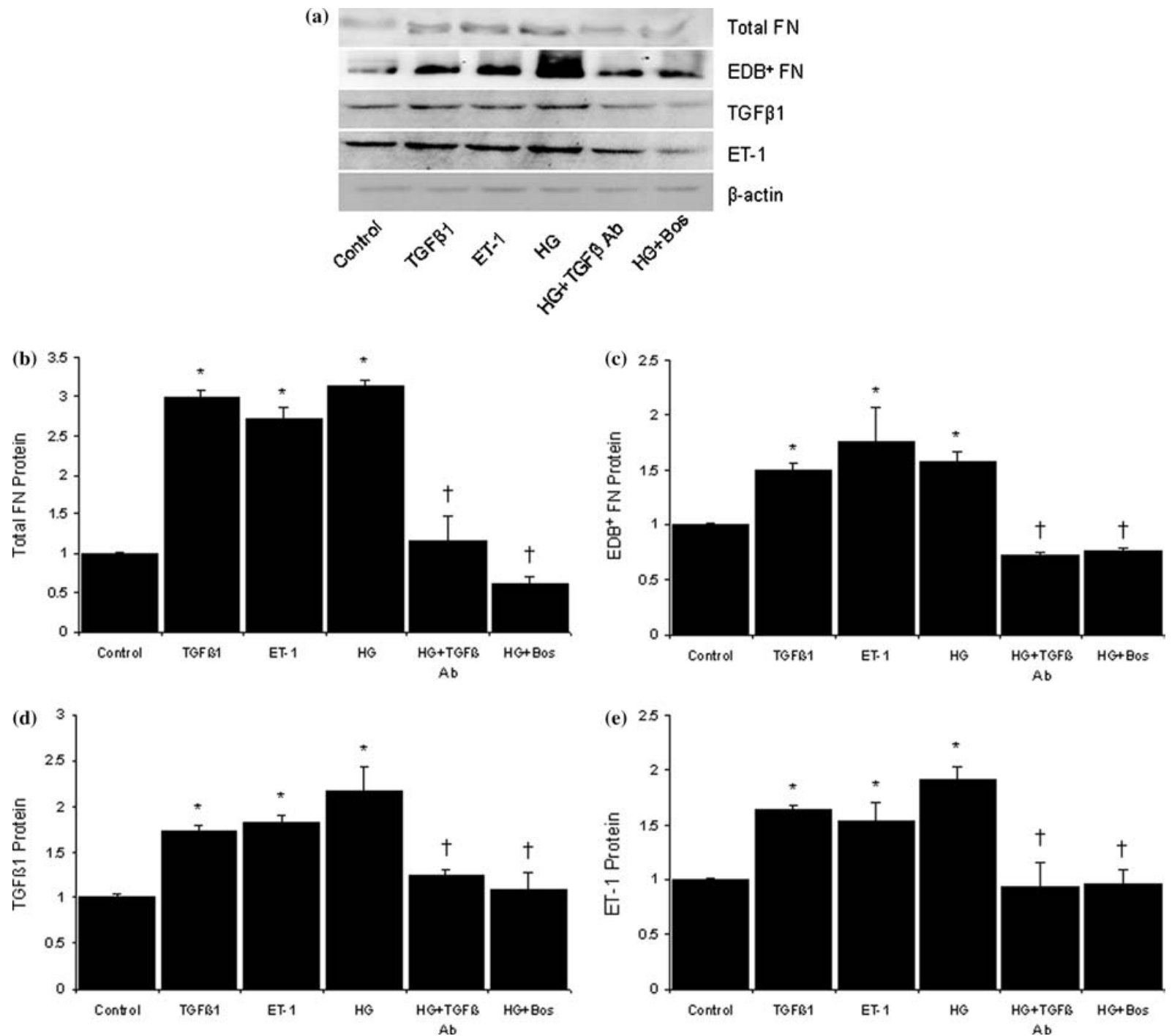

Figure 4. Western blot analysis of total FN, EDB ${ }^{+} \mathrm{FN}, \mathrm{TGF}-\beta 1$, and ET-1 in endothelial cells showing (a) representative western blots, semi-quantitative analysis of (b) Total FN, (c) $\mathrm{EDB}^{+} \mathrm{FN}$, (d) TGF- $\beta$ 1, and (e) ET-1 protein levels. Total proteins were extracted and subjected to western blot analysis using polyclonal antibodies and EDB immune serum $(* P<0.05$ as compared to control; $\uparrow P<0.05$ as compared to $\mathrm{HG})$.

\section{$E D B^{+} F N$ in endothelial proliferation and tube formation}

We next evaluated the role of $\mathrm{EDB}^{+} \mathrm{FN}$ in endothelial cell proliferation and vascular morphogenesis. Since endothelial cell proliferation is an early event in angiogenesis, we designed our experiments to assess the proliferative index of cells following inhibition of $\mathrm{EDB}^{+} \mathrm{FN}$ production. $\mathrm{EDB}^{+} \mathrm{FN}$ targeting siRNA transfection reduced the proliferative capacity of endothelial cells as assessed by measuring the number of metabolically active, viable cells using XTT assay (Figure 8c), compared to non-homologous siRNA transfection (negative control). Conversely, incubation of cells with either $50 \mathrm{ng} / \mathrm{ml}$ or $2 \mu \mathrm{g} / \mathrm{ml}$ EDB peptide significantly increased the number of viable endothelial cells as determined by XTT assay indicating increased cell proliferation.

In order to elucidate whether $\mathrm{EDB}^{+} \mathrm{FN}$ mediates morphological alterations of endothelial cells, we have utilized a well established in vitro model of angiogenesis in which endothelial cells invade a three-dimensional matrix gel and form capillary-like tubes in the presence of pro-angiogenic factors [28]. This in vitro assay allows assessment of cellular events which are necessary for the process of angiogenesis including attachment, migration, invasion, and differentiation. Our results demonstrate that endothelial cells cultured with EDB peptide formed cord-like structures within the matrix gel (Figures 8d-i). Plasma FN, FN lacking EDB segment, failed to induce endothelial tube formation at $20 \mathrm{ng} / \mathrm{ml}$ (equimolar concentration) and $2 \mu \mathrm{g} / \mathrm{ml}$ concentrations (Figures 8 g-i) providing further support for a possible role of EDB domain in vascular morphogenesis. Furthermore, scrambled peptide at either $50 \mathrm{ng} / \mathrm{ml}$ or $2 \mu \mathrm{g} / 1$ concentration showed no effect on endothelial tube formation (data not shown). These findings suggest that upregulation of $\mathrm{EDB}^{+} \mathrm{FN}$ may be involved in the alterations of endothelial cell proliferation and differentiation; processes integral to the pathogenesis of angiogenesis-dependent diseases. 

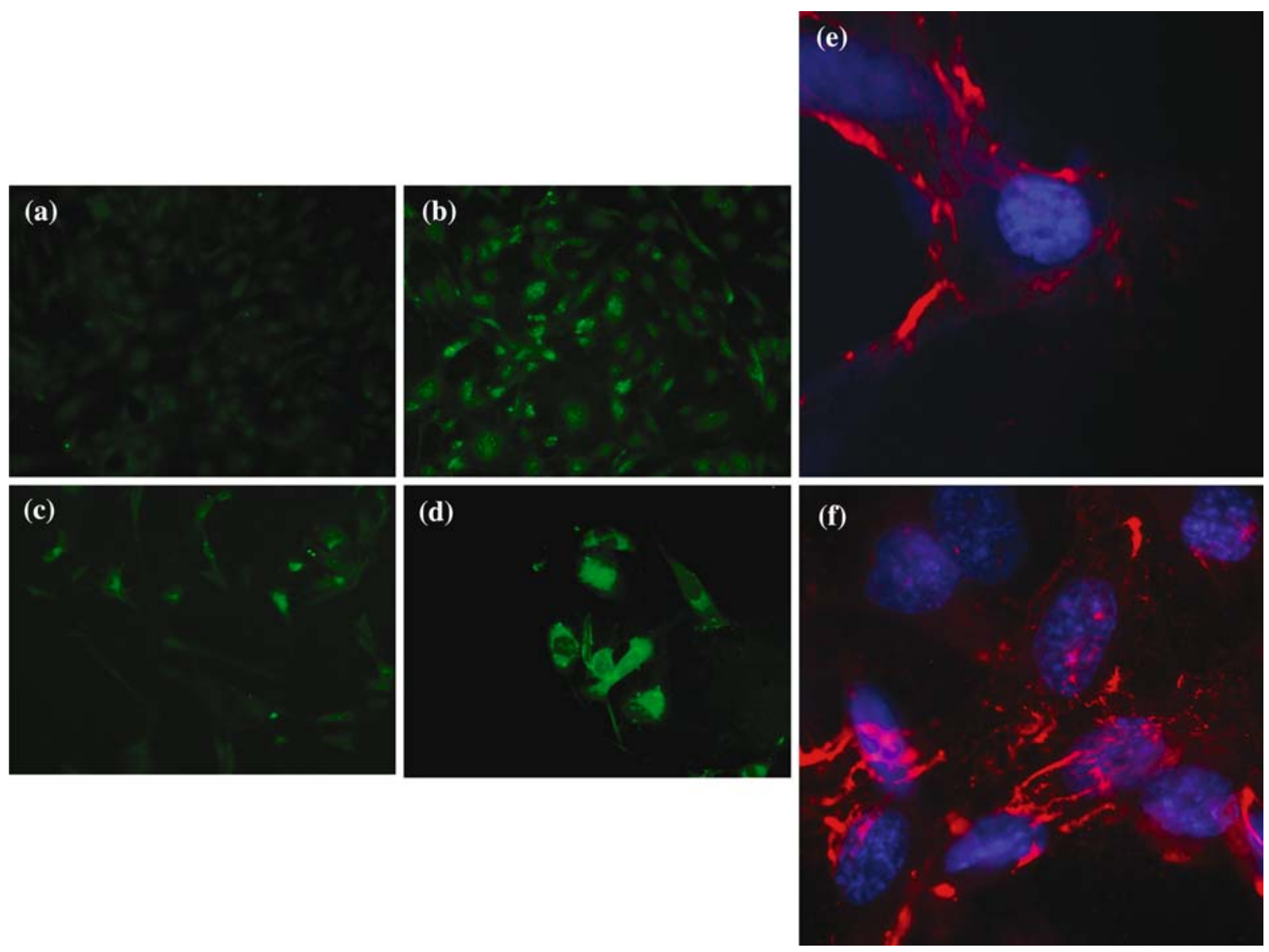

Figure 5. Immunofluorescent analysis of (a) total $\mathrm{FN}$ in $5 \mathrm{mM}$ glucose, (b) total $\mathrm{FN}$ in $25 \mathrm{mM}$ glucose, (c) $\mathrm{EDB}^{+} \mathrm{FN}$ in $5 \mathrm{mM}$ glucose, and (d) $\mathrm{EDB}^{+} \mathrm{FN}$ in $25 \mathrm{mM}$ glucose. $\mathrm{EDB}^{+} \mathrm{FN}$ fibril assembly in (e) $5 \mathrm{mM}$ glucose and (f) $25 \mathrm{mM}$ glucose. (Original magnification (a-d) $400 \times$, (e and f) $1000 \times$.)

(a)

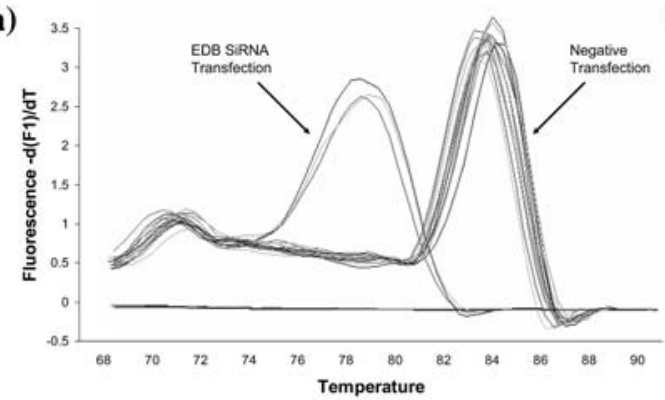

(c)

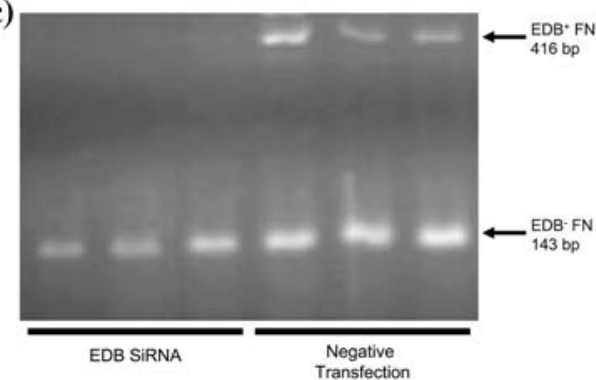

(b)

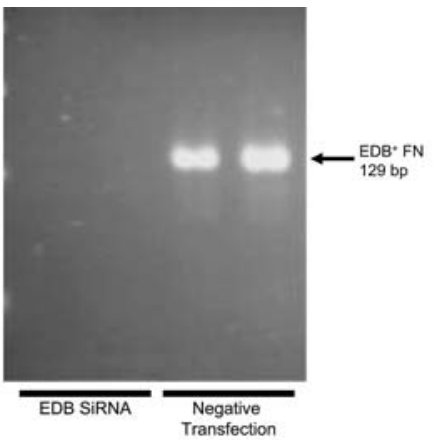

(d)

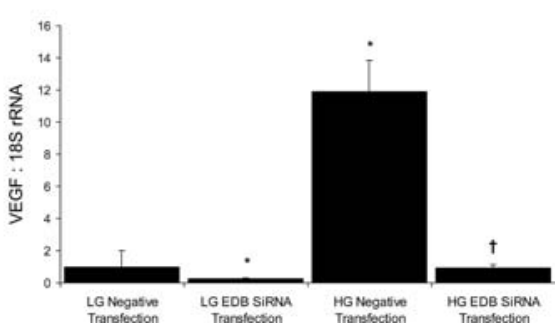

Figure 6. $\mathrm{EDB}^{+} \mathrm{FN}$ gene silencing in endothelial cells. (a) Successful oncofetal FN siRNA transfection was demonstrated by non-detectable levels of $\mathrm{EDB}^{+} \mathrm{FN}$ transcripts as assessed by melting curve analysis of post-PCR products. Low melting temperature of siRNA transfected samples indicate non-detectable levels. (b) Gel electrophoretic analysis of post-real time RT-PCR and (c) end point RT-PCR products. (d) VEGF mRNA expression following EDB siRNA transfection or negative control transfection in either $5 \mathrm{mM}$ glucose (LG) or $25 \mathrm{mM}$ glucose (HG). (For all gene silencing experiments, $n=5 /$ treatment; ${ }^{*} P<0.05$ as compared to LG negative transfection; $\dagger P<0.05$ as compared to HG negative transfection.) 

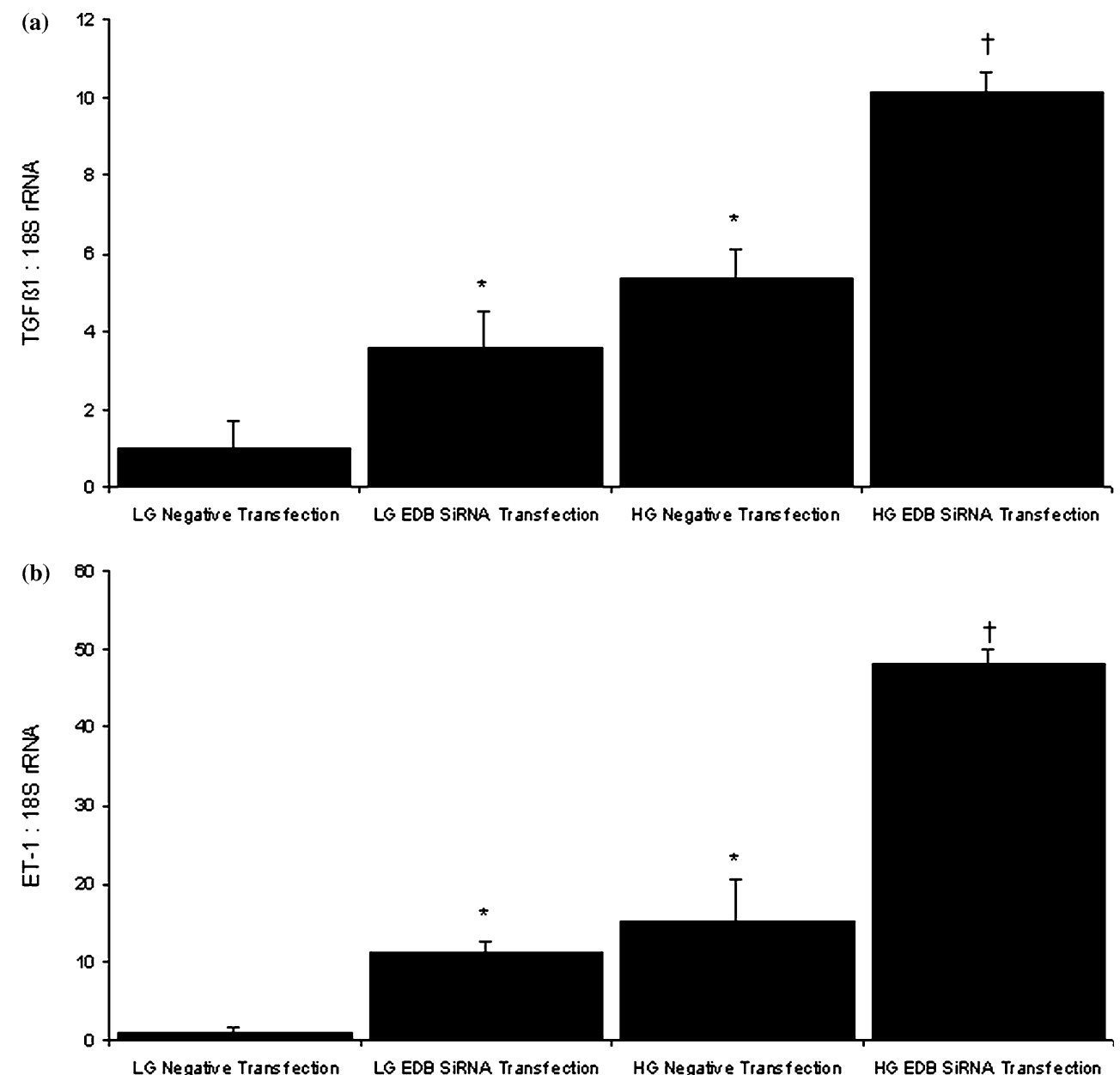

Figure 7. Effect of $\mathrm{EDB}^{+} \mathrm{FN}$ gene silencing on (a) TGF- $\beta$ mRNA expression and (b) ET-1 mRNA expression in either LG or HG. $(* P<0.05$ as compared to LG negative transfection; $\dagger P<0.05$ as compared to HG negative transfection.)

\section{Discussion}

Although $\mathrm{EDB}^{+} \mathrm{FN}$ has been shown to be prominently expressed during embryonic development and tumoral angiogenesis, little is known about the role of this embryonic isoform of $\mathrm{FN}$ in endothelial cell behavior. In the present study, we show the functional significance of $\mathrm{EDB}^{+} \mathrm{FN}$ in endothelial-derived VEGF expression and cell proliferation. Our results provide a mechanistic means by which glucose and potent mitogenic growth factors may lead to elaboration of VEGF and induce an angiogenic phenotype in the vascular endothelial cells.

Various growth factors and cytokines have been implicated in the pathogenic interactions that lead to neovascularization in PDR and tumorigenesis. Of these numerous factors, TGF- $\beta$ and ETs are of significance by virtue of their direct effects on ECM protein regulation. An important phenomenon in angiogenesis is the regulatory role of ECM on the vascular endothelial cell phenotype. Accumulating evidence suggests that the composition and the physical properties of the ECM can modulate endothelial cell behavior facilitating angiogenesis [35]. Our studies indicate that TGF- $\beta$ and ET-1 increased mRNA and protein levels of
$\mathrm{EDB}^{+} \mathrm{FN}$ which has been shown to specifically be expressed in newly formed blood vessels. It is plausible that TGF- $\beta$ and ET-1, regulate ECM composition and confer an angiogenic phenotype on vascular endothelial cells via induction of $\mathrm{EDB}^{+} \mathrm{FN}$ re-expression (Figure 9). We have previously shown that exposure of microvascular endothelial cells to high levels of glucose and fibrogenic factors also upregulates the other FN isoform, $\mathrm{EDA}^{+} \mathrm{FN}$ [7]. Whether such an upregulation is also exhibited by macrovascular endothelial cells requires further investigation. It should be noted, however, that $\mathrm{EDA}^{+} \mathrm{FN}$ does not exhibit the same restrictive pattern of expression as $\mathrm{EDB}^{+} \mathrm{FN}$. Association of $\mathrm{EDB}^{+} \mathrm{FN}$ with tumoral angiogenesis and organogenesis suggests that this embryonic $\mathrm{FN}$ isoform may regulate the process of angiogenesis. It is plausible that $\mathrm{EDA}^{+} \mathrm{FN}$ may regulate cellular events distinct from those regulated by $\mathrm{EDB}^{+} \mathrm{FN}$.

Expression of $\mathrm{EDB}^{+} \mathrm{FN}$ has been shown to be regulated in an onco-developmental manner [4-10]. The biological significance of this restricted pattern of expression still remains to be fully elucidated. In support of functional significance of $\mathrm{EDB}^{+} \mathrm{FN}$, we have demonstrated a potential role of this embryonic variant in endothelial-derived VEGF expression. VEGF has 

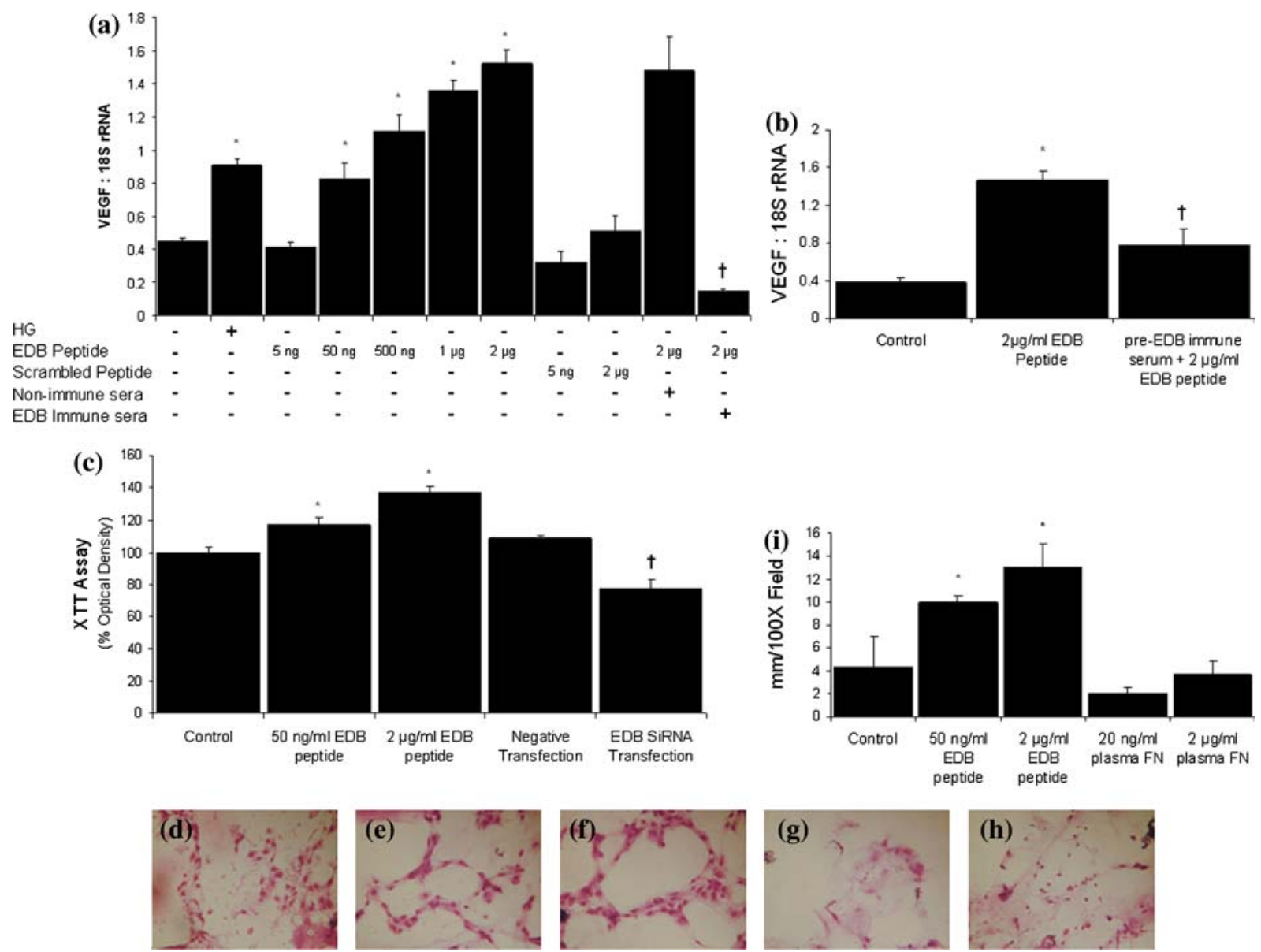

Figure 8. $\mathrm{EDB}^{+} \mathrm{FN}$ in VEGF expression, endothelial cell proliferation, and tube morphogenesis. (a) VEGF expression following incubation of endothelial cells with $25 \mathrm{mM}$ glucose, EDB peptide, scrambled peptide, and $2 \mu \mathrm{g} / \mathrm{ml}$ EDB peptide in the presence of non-immune sera (1:200) or EDB anti-sera (1:200). (b) VEGF expression following incubation of endothelial cells with $2 \mu \mathrm{g} / \mathrm{ml}$ EDB peptide with or without EDB anti-sera (1:200) pretreatment $\left(n=5 /\right.$ treatment; ${ }^{*} P<0.05$ as compared to control; $\uparrow P<0.05$ as compared to EDB peptide treatment and non-immune serum treatment; $\ddagger P<0.05$ as compared to $2 \mu \mathrm{g} / \mathrm{ml}$ EDB peptide treatment). (c) Endothelial cell proliferative capacity as measured by XTT assay following negative control siRNA and EDB siRNA transfections. In addition, proliferation was assessed following treatment with $50 \mathrm{ng} / \mathrm{ml}$ and $2 \mu \mathrm{g} / \mathrm{ml}$ EDB peptide ( $n=4$ /treatment; ${ }^{*} P<0.05$ as compared to control; $\dagger P<0.05$ as compared to negative transfection). (d-h) In vitro angiogenesis assay following treatment with (d) serum-free media alone (control), (e) $50 \mathrm{ng} / \mathrm{ml}$ EDB peptide, (f) $2 \mu \mathrm{g} / \mathrm{ml}$ EDB peptide, (g) $20 \mathrm{ng} / \mathrm{ml} \mathrm{EDB}^{-}$plasma FN, and (h) $2 \mu \mathrm{g} / \mathrm{ml} \mathrm{EDB}{ }^{-}$plasma FN. Vascular morphogenesis as evident by tube formation was evaluated following Mayer's hematoxylin-eosin staining (Sigma Chemical Co.) following $24 \mathrm{~h}$ of treatment (original magnification $400 \times$ ). (i) Semi-quantitative analysis of in vitro angiogenesis assay $(* P<0.05$ as compared to control).

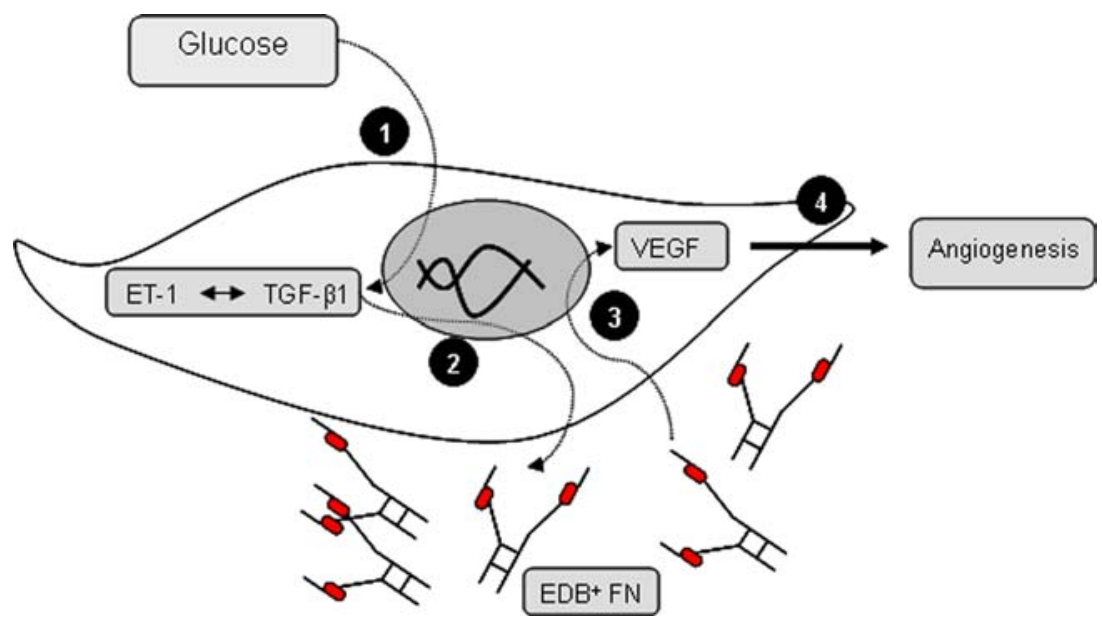

Figure 9. Schematic illustrating the putative mechanisms of $\mathrm{EDB}^{+} \mathrm{FN}$ expression and its functional significance in endothelial cells. High levels of glucose mediate alteration of ET-1 and TGF- $\beta 1$ (1) and subsequently cause upregulation of the EDB $^{+}$FN (2). Increased EDB ${ }^{+}$FN deposition leads to endothelial-derived VEGF expression (3) and angiogenesis (4). 
been shown to be an endothelial cell-specific mitogen and its expression is increased in various human cancers and in ocular neovascularization [31, 36, 37]. Recent studies show an important autocrine role of endothelial VEGF in cell proliferation and blood vessel formation [38, 39]. An important interaction between FN and VEGF by which FN potentiates VEGFmediated endothelial cell migration has also been demonstrated [40]. It is possible that such interaction is conveyed via the EDB segment of FN. Our studies do support such a notion. We have demonstrated that $\mathrm{EDB}^{+} \mathrm{FN}$ is involved in VEGF expression which could be, in part, responsible for $\mathrm{EDB}^{+} \mathrm{FN}$-mediated endothelial cell proliferation and morphogenesis.

In vivo studies aimed at determining functional role of the EDB segment of FN in both physiological and pathological angiogenesis have provided somewhat discouraging results [41, 42]. Mice with targeted deletion of the EDB segment show no phenotypic deficits. However, in agreement with our in vitro study, cells isolated from these animals exhibit reduced proliferative capacity as compared to normal counterparts [42]. A recent study has also shown no alteration of physiological and pathological angiogenesis in mice lacking EDB segment of FN [41]. Such a discrepancy in our in vitro study and recent in vivo studies should not rule out the importance of $\mathrm{EDB}^{+} \mathrm{FN}$. It should be noted that great variability in the assay used to quantitate angiogenesis in the in vivo studies [41] may have masked some of the effects of $\mathrm{EDB}^{+} \mathrm{FN}$. A limitation of knockout studies is confounding reliance on possible compensatory pathways during development. Similar contradictory results have been obtained with other factors which are believed to be involved in angiogenesis, such as basic-fibroblast growth factor (bFGF). bFGF knockout mice exhibit no drastic phenotypic deficits [43]. Similar to mice lacking EDB, FGF deletion also shows no alteration of both physiological and pathological angiogenesis [43]. However, the in vitro role of bFGF in endothelial cell proliferation and angiogenesis is very well established [44, 45]. These findings suggest that angiogenesis is a complex process which entails interaction of various signaling pathways. Normalcy of EDB-null mice certainly supports the idea. It is possible that $\mathrm{EDB}^{+} \mathrm{FN}$ may not be a requirement for vascular development; however, it may potentiate and facilitate the process. Our studies support such a notion. We have demonstrated that specific silencing of $\mathrm{EDB}^{+} \mathrm{FN}$ reduces endothelial cell proliferation. Furthermore, such inhibited production of $\mathrm{EDB}^{+} \mathrm{FN}$ also leads to reduced endothelial tube formation and expression of VEGF.

The studies described above provide functional significance of $\mathrm{EDB}^{+} \mathrm{FN}$ in endothelial VEGF expression, cell proliferation and differentiation. These results have direct bearing on our understanding of the mechanisms involved in both tumoral and non-tumoral angiogenesis. It is possible that these embryonic forms of FN are re-expressed in neovascular membranes in order to provide an FN scaffold that is potentially more appropriate for endothelial cell proliferation and differentiation. We have identified a novel mechanism by which upregulated $\mathrm{EDB}^{+} \mathrm{FN}$ could contribute to both tumoral and non-tumoral angiogenesis. This mechanism possibly involves elaboration of potent angiogenic factor, VEGF, by endothelial cells and perhaps other bystander cells. Such findings have significant implications in the development of anti-angiogenic therapies for ocular as well as tumor-induced neovascularization.

\section{Acknowledgements}

Authors acknowledge grant supports from the Canadian Diabetes Association, in honor of the late Glenn W. Liebrock, Canadian Institutes of Health Research, and Internal Research Fund of the Lawson Health Research Institute. We also thank Dr Joyce Bischoff, Vascular Biology Research Group, Children's Hospital Boston, for helpful suggestions and comments.

\section{References}

1. Folkman J. Angiogenesis in cancer, vascular, rheumatoid and other disease. Nat Med 1995; 1: 27-31.

2. Folkman J, Shing Y. Angiogenesis. J Biol Chem 1992; 267: 109314.

3. Badylak SF. The extracellular matrix as a scaffold for tissue reconstruction. Semin Cell Dev Biol 2002; 13: 377-83.

4. Castellani P, Viale G, Dorcaratto A et al. The fibronectin isoform containing the ED-B oncofetal domain: A marker of angiogenesis. Int J Cancer 1994; 59: 612-8.

5. Colombi M, Barlati S, Kornblihtt A et al. A family of fibronectin mRNAs in human normal and transformed cells. Biochem Biophys Acta 1986; 868: 207-14.

6. Demartis S, Tarli L, Borsi L et al. Selective targeting of tumour neovasculature by a radiohalogenated human antibody fragment specific for the ED-B domain of fibronectin. Eur J Nucl Med 2001; 28: 534-9.

7. Khan ZA, Cukiernik M, Gonder J et al. Oncofetal fibronectin in diabetic retinopathy. Invest Ophthalmol Vis Sci 2004; 45: 287-95.

8. Pagani F, Zagato L, Vergani $\mathrm{C}$ et al. Tissue-specific splicing pattern of fibronectin messenger RNA precursor during development and aging in rat. J Cell Biol 1991; 113: 1223-9.

9. Schwarzbauer JE, Tamkun JW, Lemischka IR et al. Three different fibronectin mRNAs arise by alternative splicing within the coding region. Cell 1983; 35: 421-31.

10. Tamkun JW, Schwarzbauer JE, Hynes RO. A single rat fibronectin gene generates three different mRNAs by alternative splicing of a complex exon. Proc Natl Acad Sci USA 1984; 81: 5140-4.

11. Zardi L, Carnemolla B, Siri A et al. Transformed human cells produce a new fibronectin isoform by preferential alternative splicing of a previously unobserved exon. EMBO J 1987; 6: 233742.

12. Roberts AB, Sporn MB, Assoian RK et al. Transforming growth factor type beta: Rapid induction of fibrosis and angiogenesis in vivo and stimulation of collagen formation in vitro. Proc Natl Acad Sci USA 1986; 83: 4167-71.

13. Yang EY, Moses HL. Transforming growth factor beta 1-induced changes in cell migration, proliferation, and angiogenesis in the chicken chorioallantoic membrane. J Cell Biol 1990; 111: 731-41. 
14. Phillips GD, Whitehead RA, Stone AM et al. Transforming growth factor beta (TGF-B) stimulation of angiogenesis: An electron microscopic study. J Submicrosc Cytol Pathol 1993; 25: $149-55$.

15. Sakamoto T, Ueno H, Sonoda $\mathrm{K}$ et al. Blockade of TGF-beta by in vivo gene transfer of a soluble TGF-beta type II receptor in the muscle inhibits corneal opacification, edema and angiogenesis. Gene Ther 2000; 7: 1915-24.

16. Kurihara H, Yoshizumi M, Sugiyama $\mathrm{T}$ et al. Transforming growth factorbeta stimulates the expression of endothelin mRNA by vascular endothelial cells. Biochem Biophys Res Commun 1989; 159: 1435-40.

17. Lee SD, Lee DS, Chun YG et al. Transforming growth factorbetal induces endothelin-1 in a bovine pulmonary artery endothelial cell line and rat lungs via cAMP. Pulm Pharmacol Ther 2000; 13: 257-65.

18. Pertovaara L, Kaipainen A, Mustonen T et al. Vascular endothelial growth factor is induced in response to transforming growth factor-beta in fibroblastic and endothelial cells. J Biol Chem 1994; 269: 6271-4.

19. Salani D, Taraboletti G, Rosano L et al. Endothelin-1 induces an angiogenic phenotype in cultured endothelial cells and stimulates neovascularization in vivo. Am J Pathol 2000; 157: 1703-11.

20. Kusuhara M, Yamaguchi K, Nagasaki K et al. Production of endothelin in human cancer cell lines. Cancer Res 1990; 50: 3257-61.

21. Vigne P, Marsault R, Breittmayer JP et al. Endothelin stimulates phosphatidylinositol hydrolysis and DNA synthesis in brain capillary endothelial cells. Biochem J 1990; 266: 415-20.

22. Chen S, Mukherjee S, Chakraborty $\mathrm{C}$ et al. High glucose induced, endothelin-dependent fibronectin synthesis is mediated via NFkappa B and AP-1. Am J Physiol Cell Physiol 2003; 284 C263-72.

23. Chen S, Khan ZA, Cukiernik M et al. Differential activation of NF-kappa B and AP-1 in increased fibronectin synthesis in target organs of diabetic complications. Am J Physiol Endocrinol Metab 2003; 284: E1089-97.

24. Schmittgen TD, Zakrajsek BA. Effect of experimental treatment on housekeeping gene expression: Validation by real-time, quantitative RTPCR. J Biochem Biophys Meth 2000; 46: 69-81.

25. Fattorusso R, Pellecchia M, Viti $F$ et al. NMR structure of the human oncofoetal fibronectin ED-B domain, a specific marker for angiogenesis. Structure Fold Des 1999; 7: 381-90.

26. Hammond SM, Boettcher S, Caudy AA et al. Argonaute2, a link between genetic and biochemical analyses of RNAi. Science 2001; 293: 1146-50.

27. Scudiero DA, Shoemaker RH, Paull KD et al. Evaluation of a soluble tetrazolium/formazan assay for cell growth and drug sensitivity in culture using human and other tumor cell lines. Cancer Res 1988; 48: 4827-33.

28. Sweeney SM, DiLullo G, Slater SJ et al. Angiogenesis in collagen I requires alpha2beta1 ligation of a GFP*GER sequence and possibly p38 MAPK activation and focal adhesion disassembly. J Biol Chem 2003; 278: 30516-24.
29. Roy S, Roth T. Proliferative effect of high glucose is modulated by antisense oligonucleotides against fibronectin in rat endothelial cells. Diabetologia 1997; 40: 1011-7.

30. Yamada KM. Cell surface interactions with extracellular materials. Annu Rev Biochem 1983; 52: 761-99.

31. Ferrara N. Role of vascular endothelial growth factor in regulation of physiological angiogenesis. Am J Physiol Cell Physiol 2001; 280: C1358-66.

32. Carnemolla B, Neri D, Castellani P et al. Phage antibodies with pan-species recognition of the oncofoetal angiogenesis marker fibronectin ED-B domain. Int J Cancer 1996; 68: 397-405.

33. Neri D, Carnemolla B, Nissim A et al. Targeting by affinitymatured recombinant antibody fragments of an angiogenesis associated fibronectin isoform. Nat Biotechnol 1997; 15: 1271-5.

34. Pini A, Viti F, Santucci A et al. Design and use of a phage display library. Human antibodies with subnanomolar affinity against a marker of angiogenesis eluted from a two-dimensional gel. J Biol Chem 1998; 273: 21769-76.

35. Relou IA, Damen CA, van der Schaft DW et al. Effect of culture conditions on endothelial cell growth and responsiveness. Tissue Cell 1998; 30: 525-30.

36. Aiello LP, Avery RL, Arrigg PG et al. Vascular endothelial growth factor in ocular fluid of patients with diabetic retinopathy and other retinal disorders. N Engl J Med 1994; 331: 1480-7.

37. Miller JW, Adamis AP, Aiello LP. Vascular endothelial growth factor in ocular neovascularization and proliferative diabetic retinopathy. Diabetes Metab Res Rev 1997; 13: 37-50.

38. Tang N, Wang L, Esko $\mathbf{J}$ et al. Loss of HIF-1alpha in endothelial cells disrupts a hypoxia-driven VEGF autocrine loop necessary for tumorigenesis. Cancer Cell 2004; 6: 485-95.

39. Helmlinger G, Endo M, Ferrara $\mathrm{N}$ et al. Formation of endothelial cell networks. Nature 2000; 405: 139-41.

40. Wijelath ES, Murray J, Rahman S et al. Novel vascular endothelial growth factor binding domains of fibronectin enhance vascular endothelial growth factor biological activity. Circ Res 2002; 91: 25-31.

41. Astrof S, Crowley D, George EL et al. Direct test of potential roles of EIIIA and EIIIB alternatively spliced segments of fibronectin in physiological and tumor angiogenesis. Mol Cell Biol 2004; 24: 8662-70.

42. Fukuda T, Yoshida N, Kataoka Y et al. Mice lacking the EDB segment of fibronectin develop normally but exhibit reduced cell growth and fibronectin matrix assembly in vitro. Cancer Res 2002; 62: $5603-10$.

43. Ozaki H, Okamoto $\mathrm{N}$, Ortega $\mathrm{S}$ et al. Basic fibroblast growth factor is neither necessary nor sufficient for the development of retinal neovascularization. Am J Pathol 1998; 153: 757-65.

44. Klagsbrun M, Vlodavsky I. Biosynthesis and storage of basic fibroblast growth factor (bFGF) by endothelial cells: Implication for the mechanism of action of angiogenesis. Prog Clin Biol Res 1988; 266: 55-61.

45. Montesano R, Vassalli JD, Baird A et al. Basic fibroblast growth factor induces angiogenesis in vitro. Proc Natl Acad Sci USA 1986; 83: 7297-301. 